\title{
Dynamics Analysis of the Main Indicators of the Higher Education System in the Regions of the Volga Federal District
}

\section{Análisis dinámico de los principales indicadores del sistema de educación superior en las regiones del Distrito Federal del Volga}

Ekaterina Anatolevna Grigoreva

$\mathrm{PhD}$ in Economics, Associate Professor of Economic theory and econometrics department, Institute of Management, Economics and Finance, Federal State Autonomous Educational Institution of Higher Education "Kazan (Volga region) Federal University" ORCID 0000-0002-1231-1098

\section{Oksana Anatolyevna Ignatjeva}

$\mathrm{PhD}$ in Economics, Associate Professor of Economic theory and econometrics department, Institute of Management, Economics and Finance, Federal State Autonomous Educational Institution of Higher Education "Kazan (Volga region) Federal University"

ORCID 0000-0002-9887-2901

\section{Elvira Anasovna Polovkina}

$\mathrm{PhD}$ in Economics, Associate Professor of Economic theory and econometrics department, Institute of Management, Economics and Finance, Federal State Autonomous Educational Institution of Higher Education "Kazan (Volga region) Federal University"

ORCID 0000-0002-2805-3660

\section{Ildar Ikramovich Abdullin}

$\mathrm{PhD}$ in Economics, Associate Professor of Economic theory and econometrics department, Institute of Management, Economics and Finance, Federal State Autonomous Educational Institution of Higher Education "Kazan (Volga region) Federal University"

ORCID 0000-0002-2708-6137

* Correspondence

E-Mail: ekaterina_kazan@mail.ru
Citation:

\footnotetext{
Tatyana Igorevna Nikitina, Aleksey Aleksandrovich Nikitin, Yakupov Bulat Ildarovich. (2021). Trends in the methodology of media consumption study in the field of cinema in Russia Propósitos y Representaciones, 9(SPE2), e1100. http://dx.doi.org/10.20511/pyr2021.v9nSPE2.1100
} 


\begin{abstract}
The relevance of the chosen topic is due to the present rise of humanity to a new wave of scientific and technological progress, which is based on various achievements in high technologies of informatics, microelectronics, nanotechnology, genetic engineering, space exploration, etc. In these conditions, the education sector, which acts as a supplier of personnel, has become a priority direction of the state economic social policy of highly developed countries.
\end{abstract}

Keywords: higher professional education, Volga Federal District, number of students, full-time education, independent educational institutions.

\title{
Resumen
}

La relevancia del tema elegido se debe al actual ascenso de la humanidad a una nueva ola de progreso científico y tecnológico, que se sustenta en diversos logros en altas tecnologías de la informática, microelectrónica, nanotecnología, ingeniería genética, exploración espacial, etc. En estos condiciones, el sector de la educación, que actúa como proveedor de personal, se ha convertido en una dirección prioritaria de la política social económica estatal de los países altamente desarrollados.

Palabras clave: educación profesional superior, Distrito Federal del Volga, número de estudiantes, educación a tiempo completo, instituciones educativas independientes.

\section{Introduction}

We have chosen the Volga Federal District to analyze changes in the main indicators of the higher education system.

Volga Federal District (VFD) is a federal district of the Russian Federation, formed by the Decree of the President of the Russian Federation of May 13, 2000. The Volga Federal District includes 14 constituent entities of the Russian Federation.

The territory of the district is $6.06 \%$ of the territory of the Russian Federation. The population of the Volga Federal District is $29,287,683$ people according to data for 2020 or $19.96 \%$ of the population of Russia. The majority of the population is urban dwellers $(72.19 \%)$, which is somewhat lower than the national average $(74.66 \%)$.

The administrative center and the largest city in the district is Nizhny Novgorod.

The share of industrial production in the Volga Federal District in the Russian economy is 23.9\% - the highest indicator (the Central Federal District ranks place). Also, in agriculture, the Volga Federal District occupies leading positions in both crop and livestock production.

The composition of the Volga Federal District is shown in Table 1.

Table 1. Composition of the Volga Federal District

\begin{tabular}{|c|l|c|c|c|}
\hline $\begin{array}{c}\text { Seq.N } \\
\text { o }\end{array}$ & \multicolumn{1}{|c|}{$\begin{array}{c}\text { Subordinate entity of the } \\
\text { Federation }\end{array}$} & Area, sq.km & $\begin{array}{c}\text { Population } \\
\text { (ppl.) }\end{array}$ & Administrative centre \\
\hline 1. & The Republic of Bashkortostan & 142947 & 403815 & Ufa \\
\hline 2. & The Kirov region & 120374 & 1262402 & Kirov \\
\hline 3. & The Mari El Republic & 23375 & 679417 & Yoshkar Ola \\
\hline 4. & The Republic of Mordovia & 26128 & 790197 & Saransk \\
\hline 5. & The Nizhny Novgorod region & 76624 & 3202946 & Nizhny Novgorod \\
\hline 6. & The Orenburg region & 123702 & 1956835 & Orenburg \\
\hline 7. & The Penza region & 43352 & 1305563 & Penza \\
\hline 8. & The Perm region & 160236 & 2599260 & Perm \\
\hline 9. & The Samara region & 53565 & 3179532 & Samara \\
\hline
\end{tabular}




\begin{tabular}{|l|l|c|c|c|}
\hline 10. & The Saratov region & 101240 & 2421895 & Saratov \\
\hline 11. & The Republic of Tatarstan & 67847 & 3902642 & Kazan \\
\hline 12. & The Udmurt Republic & 42061 & 1500955 & Izhevsk \\
\hline 13. & The Ulyanovsk region & 37181 & 1229824 & Ulyanovsk \\
\hline 14. & The Chuvash Republic & 18343 & 1217818 & Cheboksary \\
\hline
\end{tabular}

The above data show that the Volga Federal District is one of the largest federal districts of the Russian Federation, important both in industrial and agricultural terms.

The volume of investments in the Volga Federal District is $15.3 \%$ of all investments in Russia.

This confirms the importance of providing the region with highly qualified specialists, the development of the higher education system in the region. The data on higher education in the Volga Federal District are given on the basis of statistics provided on the website of the Ministry of Education (https://minobrnauki.gov.ru).

As Table 1 shows, the Republic of Tatarstan ranks 7th among 14 entities of the Volga Federal District in territory size and first in population.

\section{Results and Discussion}

In terms of the number of institutions of higher professional education and students, the Volga Federal District is one of the leaders in the Russian Federation, which can be seen from Table 2. Table also shows that the Volga Federal District is second only to the Central Federal District in both these indicators.

It should also be noted that the top 100 universities in Russia included 15 universities in the Volga Federal District. Among them are four universities of the Republic of Tatarstan (Kazan (Volga Region) Federal University, Kazan State Medical University, A.N. Tupolev Kazan National Research Technical University - KAI, and Kazan National Research Technological University - KKhTI); three universities of the Samara region (Academician S.P. Korolev Samara National Research University, Samara State Medical University, Samara State Technical University); two of the Republic of Bashkortostan (Ufa State Aviation Technical University, Bashkir State University) and two - Saratov Region (V.I. Razumovsky Saratov State Medical University, N.G. Chernyshevsky Saratov National Research State University). This includes universities with the best conditions for quality education, a high level of demand for graduates by employers and a level of research activities.

Table 2. The number of students by federal districts (people) and the number of institutions of higher professional education (HPE) in 2019 (https://minobrnauki.gov.ru)

\begin{tabular}{|c|c|c|c|}
\hline $\begin{array}{c}\text { Seq.N } \\
\mathbf{o}\end{array}$ & Region & $\begin{array}{c}\text { The number of } \\
\text { students, people }\end{array}$ & $\begin{array}{c}\text { The number of } \\
\text { educational institutions of } \\
\text { HPE }\end{array}$ \\
\hline \multicolumn{2}{|c|}{ The Russian Federation } & 4068327 & 724 \\
\hline 1. & The Volga Federal District & 807917 & 112 \\
\hline 2. & The Central Federal District & 1268510 & 262 \\
\hline 3. & The North-Western Federal District & 418905 & 87 \\
\hline 4. & The Southern Federal District & 404562 & 59 \\
\hline 5. & The North Caucasus Federal District & 208610 & 43 \\
\hline 6. & The Urals Federal District & 299190 & 72 \\
\hline 7. & The Siberian Federal District & 475879 & 40 \\
\hline 8. & The Far Eastern Federal District & 184754 & \\
\hline
\end{tabular}

However, analysis of changes in the number of independent educational institutions of higher professional education (HPE) shows that over the past five years the number of educational 
organizations of HPE in the Volga Federal District has decreased by $15 \%$. This can be seen from the data in Table 3.

Table 3. Number of educational institutions of HPE

\begin{tabular}{|c|c|c|c|c|c|}
\hline Seq. No & Region & 2015 & 2017 & 2018 & 2019 \\
\hline \multicolumn{2}{|c|}{ The Russian Federation } & 896 & 766 & 741 & 724 \\
\hline 1. & The Volga Federal District & 131 & 117 & 116 & 112 \\
\hline 2. & The Republic of Bashkortostan & 11 & 10 & 10 & 10 \\
\hline 3. & The Mari El Republic & 3 & 3 & 3 & 3 \\
\hline 4. & The Republic of Mordovia & 3 & 3 & 3 & 2 \\
\hline 5. & The Republic of Tatarstan & 25 & 24 & 23 & 22 \\
\hline 6. & The Udmurt Republic & 7 & 7 & 7 & 7 \\
\hline 7. & The Chuvash Republic & 5 & 4 & 4 & 4 \\
\hline 8. & The Perm region & 12 & 10 & 10 & 10 \\
\hline 9. & The Kirov region & 6 & 4 & 4 & 4 \\
\hline 10. & The Nizhny Novgorod region & 13 & 11 & 11 & 10 \\
\hline 11. & The Orenburg region & 5 & 5 & 5 & 6 \\
\hline 12. & The Penza region & 4 & 4 & 5 & 5 \\
\hline 13. & The Samara region & 25 & 20 & 19 & 17 \\
\hline 14. & The Saratov region & 7 & 7 & 7 & 7 \\
\hline
\end{tabular}

This reduction affected the Samara region the most, where 5 military-industrial organizations were closed in 5 years.

This applies to an even greater extent to private independent educational institutions of higher professional education, where the reduction over 5 years in the Volga Federal District was $25 \%$.

The reduction in the number of educational institutions went hand in hand with the reduction in the number of students, as the data in Table 4 show.

Table 4. Dynamics of the number of students in educational institutions of higher professional education, people (www.fiilledu.ru)

\begin{tabular}{|c|c|c|c|c|c|}
\hline Seq. No & Region & 2015 & 2017 & 2018 & 2019 \\
\hline \multicolumn{2}{|c|}{ The Russian Fedration } & 4766479 & 4245885 & 4161672 & 4068327 \\
\hline 1. & The Volga Federal District & 946023 & 851728 & 828791 & 807917 \\
\hline 2. & The Republic of Bashkortostan & 114417 & 103552 & 100525 & 97187 \\
\hline 3. & The Mari El Republic & 19645 & 19038 & 18357 & 17267 \\
\hline 4. & The Republic of Mordovia & 30148 & 27813 & 26365 & 25461 \\
\hline 5. & The Republic of Tatarstan & 163201 & 149927 & 146913 & 143941 \\
\hline 6. & The Chunt Republic & 51290 & 45690 & 44054 & 43388 \\
\hline 7. & The Perm region & 38349 & 35403 & 34387 & 34458 \\
\hline 8. & The Kirov region & 36369 & 56572 & 55169 & 54033 \\
\hline 9. & The Nizhny Novgorod region & 98192 & 32854 & 31199 & 28911 \\
\hline 10. & The Orenburg region & 53322 & 463173 & 84776 & 83490 \\
\hline 11. & The Penza region & 40159 & 33648 & 33296 & 32503 \\
\hline 12. & The Samara region & 110963 & 99850 & 96920 & 94568 \\
\hline 13. & The Saratov region & 84494 & 75998 & 74594 & 73611 \\
\hline 14. & The Ulyanovsk region & 39272 & 36895 & 36345 & 35589 \\
\hline
\end{tabular}

The total number of students in the Volga Federal District has decreased by $14.5 \%$ over the past 5 years, which roughly coincides with the decrease in the number of students in the Russian Federation - 14.6\%. 
Part-time students underwent the greatest reduction, which is most represented by the data in Table 5, namely, 33\% in the Russian Federation and 30.6\% in the Volga Federal District.

Table 5. The number of students enrolled in part-time education, people (www.fiilledu.ru)

\begin{tabular}{|c|c|c|c|c|c|}
\hline Seq. No. & Region & 2015 & 2017 & 2018 & 2019 \\
\hline & The Russian Federation & 2237789 & 1730417 & 1636297 & 1500272 \\
\hline \multicolumn{2}{r|}{ The Volga Federal District } & 465699 & 369346 & 347851 & 323063 \\
\hline 1. & The Republic of Bashkortostan & 56357 & 47564 & 46459 & 44169 \\
\hline 2. & The Mari El Republic & 9359 & 7727 & 6855 & 5727 \\
\hline 3. & The Republic of Mordovia & 14177 & 11641 & 10382 & 9408 \\
\hline 4. & The Republic of Tatarstan & 79547 & 62901 & 58033 & 52286 \\
\hline 5. & The Udmurt Republic & 29201 & 23309 & 22183 & 21273 \\
\hline 6. & The Chuvash Republic & 20150 & 16293 & 15814 & 15788 \\
\hline 7. & The Perm region & 32082 & 23299 & 21439 & 19786 \\
\hline 8. & The Kirov region & 19049 & 15806 & 13703 & 11798 \\
\hline 9. & The Nizhny Novgorod region & 46024 & 36605 & 33691 & 31387 \\
\hline 10. & The Orenburg region & 30118 & 22715 & 21984 & 19885 \\
\hline 11. & The Penza region & 19291 & 12686 & 12557 & 12003 \\
\hline 12. & The Samara region & 49725 & 40921 & 38572 & 35426 \\
\hline 13. & The Saratov region & 41376 & 31507 & 30760 & 29893 \\
\hline 14. & The Ulyanovsk region & 19243 & 16372 & 15419 & 14234 \\
\hline
\end{tabular}

As Table 6 shows, part-time students of private universities have undergone the maximum reduction: $63.2 \%$ in the Russian Federation, and $74.6 \%$ in the Volga Federal District.

Table 6. The number of part-time students in private universities, people (http://obrnadzor.gov.ru/)

\begin{tabular}{|c|c|c|c|c|c|}
\hline $\begin{array}{c}\text { Seq. } \\
\text { No }\end{array}$ & Region & 2015 & 2017 & 2018 & 2019 \\
\hline \multicolumn{2}{|c|}{ The Russian Federation } & 570100 & 317578 & 269562 & 209599 \\
\hline \multicolumn{2}{|c|}{ The Volga Federal District } & 100624 & 48130 & 35450 & 25593 \\
\hline 2. & The Republic of Bashkortostan & 12030 & 7317 & 5934 & 4022 \\
\hline 3. & The Mari El Republic & 2923 & 1940 & 1068 & 480 \\
\hline 4. & The Republic of Mordovia & 4271 & 2452 & 1434 & 1155 \\
\hline 5. & The Republic of Tatarstan & 31989 & 18618 & 14903 & 11460 \\
\hline 6. & The Udmurt Republic & 6381 & 1697 & 530 & 461 \\
\hline 7. & The Chuvash Republic & 4386 & 2903 & 2498 & 2078 \\
\hline 8. & The Perm region & 6033 & 1881 & 829 & 561 \\
\hline 9. & The Kirov region & 3491 & 1686 & 1309 & 645 \\
\hline 10. & The Nizhny Novgorod region & 7858 & 2842 & 1232 & 806 \\
\hline 11. & The Orenburg region & 4873 & 1480 & 1003 & 746 \\
\hline 12. & The Penza region & 2768 & 310 & 597 & 375 \\
\hline 13. & The Samara region & 6810 & 3678 & 2998 & 2124 \\
\hline 14. & The Saratov region & 4533 & 1131 & 888 & 563 \\
\hline
\end{tabular}

State funded students have undergone the lowest reduction over the last five years: $2.2 \%$ in the Russian Federation, and 4.3\% in the Volga Federal District (Table 7). 
Table 7. The number of students whose training was paid for at the expense of the federal budget, people (http://obrnadzor.gov.ru/)

\begin{tabular}{|c|c|c|c|c|c|}
\hline $\begin{array}{c}\text { Seq. } \\
\text { No }\end{array}$ & Region & 2015 & 2017 & 2018 & 2019 \\
\hline \multicolumn{2}{|c|}{ The Russian Federation } & & 1843016 & 1849256 & 1827862 \\
\hline \multicolumn{2}{|c|}{ The Volga Federal District } & & 361127 & 359493 & 352462 \\
\hline 1. & The Republic of Bashkortostan & 41624 & 39468 & 38863 & 38251 \\
\hline 2. & The Mari El Republic & 11672 & 12347 & 12505 & 11825 \\
\hline 3. & The Republic of Mordovia & 15134 & 14576 & 14112 & 13434 \\
\hline 4. & The Republic of Tatarstan & 59057 & 58067 & 57836 & 56986 \\
\hline 5. & The Udmurt Republic & 19054 & 19981 & 20026 & 19586 \\
\hline 6. & The Chuvash Republic & 13133 & 12459 & 12189 & 12308 \\
\hline 7. & The Perm region & 29135 & 29514 & 29626 & 29470 \\
\hline 8. & The Kirov region & 13902 & 13829 & 13521 & 12823 \\
\hline 9. & The Nizhny Novgorod region & 36312 & 36119 & 36308 & 36265 \\
\hline 10. & The Orenburg region & 22291 & 20724 & 20667 & 19909 \\
\hline 11. & The Penza region & 16653 & 14925 & 14874 & 14466 \\
\hline 12. & The Samara region & 42020 & 41026 & 40693 & 40193 \\
\hline 13. & The Saratov region & 31930 & 31511 & 31499 & 30423 \\
\hline 14. & The Ulyanovsk region & 16495 & 16581 & 16774 & 16523 \\
\hline
\end{tabular}

We shall consider the possible reasons for a decrease in the number of university students and higher education institutions.

One of the reasons for the decline in the number of students could be the demographic situation associated with the consequences of the Great Patriotic War and the crisis of the 90s.

Table 8. Admission of students to HPE, people (https://br-analytics.ru)

\begin{tabular}{|c|c|c|c|c|c|}
\hline $\begin{array}{c}\text { Seq. } \\
\text { No }\end{array}$ & Region & 2015 & 2017 & 2018 & 2019 \\
\hline \multicolumn{2}{|c|}{ The Russian Federation } & & 1141988 & 1147932 & 1129381 \\
\hline & The Volga Federal District & & 227968 & 225312 & 221045 \\
\hline 1. & The Republic of Bashkortostan & 29911 & 28105 & 26363 & 26244 \\
\hline 2. & The Mari El Republic & 5223 & 5751 & 5399 & 4676 \\
\hline 3. & The Republic of Mordovia & 7577 & 7040 & 6751 & 6293 \\
\hline 4. & The Republic of Tatarstan & 44119 & 41166 & 41807 & 42725 \\
\hline 5. & The Udmurt Republic & 15027 & 13977 & 12810 & 12263 \\
\hline 6. & The Chuvash Republic & 9406 & 8550 & 8958 & 8843 \\
\hline 7. & The Perm region & 16089 & 14468 & 15562 & 14621 \\
\hline 8. & The Kirov region & 9263 & 8482 & 7852 & 7312 \\
\hline 9. & The Nizhny Novgorod region & 24368 & 24240 & 22490 & 23392 \\
\hline 10. & The Orenburg region & 12337 & 11783 & 11975 & 10065 \\
\hline 11. & The Penza region & 9588 & 8656 & 8360 & 8125 \\
\hline 12. & The Samara region & 29903 & 26177 & 27390 & 26908 \\
\hline 13. & The Saratov region & 22321 & 20299 & 20240 & 20909 \\
\hline 14. & The Ulyanovsk region & 10131 & 9274 & 9355 & 8669 \\
\hline
\end{tabular}


Table 9. Data on the number of 11th grade school leavers and admission to universities, people (https://br-analytics.ru)

\begin{tabular}{|c|c|c|c|c|c|}
\hline $\begin{array}{c}\text { Seq. } \\
\text { No }\end{array}$ & Region & 2015 & 2017 & 2018 & 2019 \\
\hline 1. & $\begin{array}{c}\text { The number of 11th grade school leavers of } \\
\text { general educational institutions of the } \\
\text { Russian Federation, thousand people }\end{array}$ & 730.9 & 716.9 & 729.1 & 733.0 \\
\hline 2. & $\begin{array}{c}\text { The number of 11th grade school leavers of } \\
\text { general educational institutions of the Volga } \\
\text { Federal District, thousand people }\end{array}$ & 160.7 & 157.6 & 160.3 & 161.3 \\
\hline 3. & $\begin{array}{c}\text { Admission of students to Universities of the } \\
\text { Russian Federation, thousand people }\end{array}$ & 1221.8 & 1142.0 & 1147.9 & 1129.4 \\
\hline 4. & $\begin{array}{c}\text { Admission of students to Universities of the } \\
\text { Volga Federal District, thousand people }\end{array}$ & 245.3 & 228.0 & 225.3 & 221.0 \\
\hline
\end{tabular}

However, comparison of the birth rate and the numbers of student enrollment (Tables 8 and 9) shows that 1997, when the majority of university applicants were born, is the year of the minimum birth rate, which started growing later. This is also indicated by the number of 11th grade graduates from general educational institutions, which also, as a rule, grew in the years indicated.

\section{Summary}

In our opinion, the main reasons may be the drop in the living standards of the residents of the Russian Federation in the indicated years and, as a consequence, the lack of the necessary funds to receive education on a paid basis. This is also indicated by the practical invariability of the number of federal state students and a sharp decrease in the number of students of private universities, parttime students and students of state universities studying on a paid basis. Another possible factor may be an administrative approach aimed at closing private universities, where the cost of education is significantly lower than in public ones.

The reduction in the number of universities and students inevitably led to a reduction in the number of teaching staff (Table 10).

Table 10. The number of teaching staff, people (Zuev \& Gretchenko, 2013)

\begin{tabular}{|c|c|c|c|c|c|}
\hline $\begin{array}{c}\text { Seq. } \\
\text { No }\end{array}$ & Region & 2015 & 2017 & 2018 & 2019 \\
\hline \multicolumn{7}{|c|}{ The Russian Federation } & 279758 & 245078 & 236057 & 229334 \\
\hline \multicolumn{2}{|c|}{ The Volga Federal District } & 51447 & 44854 & 42714 & 41336 \\
\hline 1. & The Republic of Bashkortostan & 6001 & 5240 & 5077 & 4884 \\
\hline 2. & The Mari El Republic & 1004 & 938 & 932 & 887 \\
\hline 3. & The Republic of Mordovia & 1929 & 1626 & 1502 & 1468 \\
\hline 4. & The Republic of Tatarstan & 8711 & 7864 & 7394 & 7220 \\
\hline 5. & The Udmurt Republic & 2382 & 2105 & 2011 & 1981 \\
\hline 6. & The Chuvash Republic & 1860 & 1515 & 1417 & 1363 \\
\hline 7. & The Perm region & 3951 & 3448 & 3309 & 3200 \\
\hline 8. & The Kirov region & 1553 & 1350 & 1285 & 1224 \\
\hline 9. & The Nizhny Novgorod region & 5870 & 5000 & 4839 & 4719 \\
\hline 10. & The Orenburg region & 2698 & 2351 & 2149 & 2058 \\
\hline 11. & The Penza region & 2070 & 1767 & 1696 & 1678 \\
\hline 12. & The Samara region & 6338 & 5632 & 5320 & 5039 \\
\hline 13. & The Saratov region & 5019 & 4289 & 4095 & 3968 \\
\hline 14. & The Ulyanovsk region & 2061 & 1729 & 1688 & 1647 \\
\hline
\end{tabular}

The number of teaching staff in the Russian Federation has decreased over the past 5 years 
by $18 \%$, and in the Volga Federal District by $20 \%$.

Another important moment is a drop in the number of Ph.D. and candidates of science among teaching staff at universities (Tables 11 and 12). Thus, the number of Ph.D. teaching in the universities of the Russian Federation has decreased over 5 years by $14.3 \%$, and in the Volga Federal District by $14.2 \%$. An even greater reduction took place among candidates of sciences. In the Russian Federation, the number of candidates of science has decreased by $16.9 \%$, and in the Volga Federal District by $17.6 \%$.

Table 11. The number of doctors of science in universities, people (Zuev \& Gretchenko, 2013)

\begin{tabular}{|c|c|c|c|c|c|}
\hline Seq. No & Region & 2015 & 2017 & 2018 & 2019 \\
\hline \multirow{2}{*}{\multicolumn{2}{|c|}{$\begin{array}{l}\text { The Russian Federation } \\
\text { The Volga Federal District }\end{array}$}} & 42357 & 38386 & 37126 & 36283 \\
\hline & & 7497 & 6806 & 6619 & 6436 \\
\hline 1. & The Republic of Bashkortostan & 959 & 875 & 841 & 819 \\
\hline 2. & The Mari El Republic & 129 & 120 & 123 & 117 \\
\hline 3. & The Republic of Mordovia & 279 & 247 & 234 & 224 \\
\hline 4. & The Republic of Tatarstan & 1263 & 1165 & 1141 & 1120 \\
\hline 5. & The Udmurt Republic & 322 & 304 & 293 & 280 \\
\hline 6. & The Chuvash Republic & 207 & 186 & 179 & 170 \\
\hline 7. & The Perm region & 514 & 475 & 473 & 460 \\
\hline 8. & The Kirov region & 175 & 153 & 140 & 142 \\
\hline 9. & The Nizhny Novgorod region & 833 & 781 & 764 & 735 \\
\hline 10. & The Orenburg region & 323 & 313 & 302 & 288 \\
\hline 11. & The Penza region & 317 & 258 & 260 & 254 \\
\hline 12. & The Samara region & 926 & 868 & 850 & 830 \\
\hline 13. & The Saratov region & 972 & 831 & 803 & 781 \\
\hline 14. & The Ulyanovsk region & 278 & 230 & 216 & 216 \\
\hline
\end{tabular}

Table 12. The number of candidates of science in universities, people (Zuev \& Gretchenko, 2013)

\begin{tabular}{|c|c|c|c|c|c|}
\hline $\begin{array}{c}\text { Seq. } \\
\text { No }\end{array}$ & Region & 2015 & 2017 & 2018 & 2019 \\
\hline \multicolumn{2}{|c|}{ The Russian Federation } & 159965 & 141662 & 136528 & 132938 \\
\hline 1. & The Volga Federal District & 30771 & 27375 & 26033 & 25356 \\
\hline 2. & The Republic of Bashkortostan & 3628 & 3278 & 3143 & 3032 \\
\hline 3. & The Mari El Republic & 649 & 607 & 593 & 568 \\
\hline 4. & The Republic of Mordovia & 1342 & 1164 & 1075 & 1037 \\
\hline 5. & The Republic of Tatarstan & 5229 & 4758 & 4471 & 4412 \\
\hline 6. & The Udmurt Republic & 1461 & 1281 & 1224 & 1213 \\
\hline 7. & The Chuvash Republic & 1120 & 931 & 866 & 842 \\
\hline 8. & The Perm region & 2121 & 1988 & 1898 & 1882 \\
\hline 9. & The Kirov region & 951 & 876 & 862 & 828 \\
\hline 10. & The Nizhny Novgorod region & 3386 & 2902 & 2818 & 2749 \\
\hline 11. & The Orenburg region & 1697 & 1514 & 1406 & 1350 \\
\hline 12. & The Penza region & 1294 & 1106 & 1043 & 1033 \\
\hline 13. & The Samara region & 3625 & 3275 & 3113 & 2983 \\
\hline 14. & The Saratov region & 3049 & 2622 & 2485 & 2414 \\
\hline
\end{tabular}

As a result, the number of students per teacher, Ph.D. and candidate of sciences on average has significantly increased. For the Volga Federal District, the ratio in 2015 was 18.4, 126.2, and 30.7 , respectively, and in $2019-22.9,147.0$, and 31.9, respectively. This indicates a decrease in the provision of qualified teachers, despite the decrease in the number of students. 


\section{Conclusions}

In this regard, to identify the qualitative component of satisfaction with the availability and quality of higher education in the regions of the Volga Federal District, we conducted a content analysis of the information presented in the media about the availability and quality of higher education. We selected five information portals of the largest socio-political publications of the Volga Federal District (Strategy for the development of education in the Republic of Tatarstan for 2017-2021 and up to 2030): Business-online (Republic of Tatarstan), Bashinform.rf (Republic of Bashkortostan), Saratovnews.ru (Saratov region), Ulyanovskaya Pravda (Ulyanovsk region), and Vyatka oblastnaya (Kirov region).

Content analysis was carried out for the period from 01.01.2019 to 31.01.2019 inclusively.

The choice of these sources is due, firstly, to their popularity among readers - the selected publications were included in the TOP-20 of the most cited media in the Volga Federal District (Kalimullin et al., 2016), and, secondly, informational Internet portals, electronic versions of newspapers have an almost unlimited audience of readers.

The categories of content analysis were the quality of higher education and the availability of higher education (Vershitskaya et al., 2020; Berestova et al., 2020). An article was taken as a unit of account, that conveys a negative, neutral or positive attitude towards the studied characteristics of the higher education system. Table 13 presents the results of the conducted content analysis.

Table 13. Content analysis of media publications that characterize the quality and availability of higher education in 2019

\begin{tabular}{|c|c|c|c|c|c|c|c|}
\hline $\begin{array}{c}\text { №oo } \\
\Pi / \Pi\end{array}$ & \multirow[t]{2}{*}{ Source } & \multicolumn{3}{|c|}{$\begin{array}{l}\text { The availability of higher } \\
\text { education }\end{array}$} & \multicolumn{3}{|c|}{$\begin{array}{l}\text { The quality of higher } \\
\text { education }\end{array}$} \\
\hline $\begin{array}{l}\text { Seq. } \\
\text { No }\end{array}$ & & «-» & «0» & «+» & «-» & $\ll 0 »$ & «+» \\
\hline 1. & "Business online" & 15 & 35 & 31 & 20 & 12 & 23 \\
\hline 2. & Bashinform.rf & 31 & 18 & 13 & 16 & 14 & 22 \\
\hline 3. & "Nizhny Novgorod online" & 13 & 20 & 16 & 8 & 12 & 14 \\
\hline 4. & Orenburg.ru & 18 & 16 & 10 & 8 & 10 & 16 \\
\hline 5. & "Mariyskaya pravda" & 13 & 17 & 19 & 10 & 14 & 8 \\
\hline
\end{tabular}

The largest number of publications related to higher education was posted in Business Online - 136, the smallest - in Mariyskaya Pravda - 79. The largest number of "positive" publications both on the availability and the quality of higher education were posted in Business Online. This is quite understandable - the Republic of Tatarstan is one of the leaders in terms of the number of students and their provision with budget places. In general, the number of "negative" reviews regarding the availability of higher education slightly exceeds the number of "positive" ones ( 90 and 89 , respectively). The assessment of the quality of higher education shows an opposite situation - 83 "positive" and 62 "negative". The problem of accessibility of higher education interests the media much more than the quality of education (285 publications versus 207). In general, the picture corresponds to a study conducted in 2015 on the availability and quality of education (Kvon et al., 2019; Ignateva et al., 2019).

\section{Acknowledgements}

The work is performed according to tohe Russian Government Program of Competitive Growth of Kazan Federal University. 


\section{References}

All universities in Russia [Electronic resource] Access mode: www.fiilledu.ru

Berestova, A.V., Lazareva, A.V., \& Leontyev, V.V. (2020). New tendencies in studies within vocational education in Russia. International Journal of Instruction, 13(1), 886-900.

Ignateva, O.A., Mustafin, A.N., \& Maksimova, M.N. (2019). Effective realization of social partnership and supply chain management in the Russian Federation economy. International Journal of Supply Chain Management, 8(4), 572-576.

Kalimullin, A.M., Khodyreva, E.A., \& Koinova-Zoellner, J. (2016). Development of internal system of education quality assessment at a university.International Journal of Environmental and Science Education, 11(13), 6002-6013.

Kvon, G.M., Vaks, V.B., Kalimullin, A.M., Bayanova, A.R., Shaidullina, A.R., Dolzhikova, A.V., \& Lapidus, N.I. (2019). Developing the informational and digital environment of a university: Problem analysis and assessment. Eurasia Journal of Mathematics, Science and Technology Education, 15(10), Article No: em1767,.

Official site of the Ministry of Science and Higher Education [Electronic resource]: Access mode: https://minobrnauki.gov.ru/

Official website of the Federal Service for Supervision in Education and Science [Electronic resource]. Access mode: http://obrnadzor.gov.ru/

Rating of the Volga Federal District mass media by citation in social media, June 2019 [Electronic resource]: Access mode: https://br-analytics.ru/blog/volga-federal-region-massmediaratings/

Strategy for the development of education in the Republic of Tatarstan for 2017-2021 and up to 2030 [Text]. Electronic resource: http://mon.tatarstan.ru/rus/file/pub/pub_1040459.pdf (accessed: 30.03.2019).

Vershitskaya, E.R., Mikhaylova, A.V., Gilmanshina, S.I., Dorozhkin, E.M., Epaneshnikov, V.V. (2020). Present-day management of universities in Russia: Prospects and challenges of elearning. Education and Information Technologies, 25(1), 611-621.

Zuev, V.M., \& Gretchenko, A.I. (2013). Problems of higher education in terms of the new law "On education in the Russian Federation" [Text]. Bulletin of G.V. Plekhanov Russian University of Economics, 2(56), 5-12. 